\title{
Does Fiscal Policy Matter for Growth? Empirical Evidence from Pakistan
}

\author{
Rabia Nazir ${ }^{1,2}$, Mumtaz Anwar ${ }^{2},{\text { Mamoona } \operatorname{Irshad}^{2} \& \text { Ayza Shoukat }}^{2}$ \\ ${ }^{1}$ Department of Economics, The Islamia University of Bahawalpur, Pakistan \\ ${ }^{2}$ University of Punjab Lahore, Pakistan \\ Correspondence: Rabia Nazir, Lecturer, The Islamia University of Bahawalpur, Bahawalnagar Campus, District \\ Bahawalnagar Province, Punjab, Pakistan. Tel: 923-36-635-0651. E-mail: rabia.nazir@iub.edu.pk
}

Received: December 18, 2012

doi:10.5539/ijef.v5n3p205

\begin{abstract}
The present study is designed to investigate the short and long run impact of fiscal strategy variables on GDP growth of Pakistan by employing Johanson co-integration technique and ECM. Data on GDP per capita, per capita real public revenues, government final consumption expenditures, discount rate, trade openness, and gross fixed capital formation has been gained from various sources like world development indicators, FBS Pakistan and the economic survey of Pakistan (various sources). In long run government consumption expenditures and public revenues both are affecting GDP significantly with negative and positive coefficients respectively. Moreover ECM indicates that approximately $37 \%$ of the disequilibrium error is corrected in each period which is a good speed of convergence. The Reduction of government consumption expenditures and enhancing revenue generation efficiency is recommended for better outcomes of fiscal policy in Pakistan.
\end{abstract}

Keywords: fiscal policy, short and long run, ADF, cointigration, GDP growth

\section{Introduction}

Concept of economic growth is getting tremendous importance from researchers and policy makers because of the fact that economic progress plays a vibrant role in the development of social, economic and political welfare of nations. Fiscal trade and monetary policies play an important role to boost the level of economic growth (Jawaid et al., 2011).

Among above stated macro level policies fiscal policy is key government policy to lead the economy towards faster economic growth. Fiscal policy of the current period reflects the pattern of the economy in the coming time period. Fiscal policy uses government spending and taxes to control and stimulate economic growth. Theoretically fiscal policy can be employed to affect inflation, collective demand, and level of economic activity, allocation and distribution of resources and to avoid economic depression. Fiscal policy actions consist of two set of actions: first is discretionary action in which government sets tax rate, tax base and the size of the government. On the other hand are the automatic stabilizers in which the variables change due to change in the economic environment like during economic boom tax revenues will increase automatically and spending on social benefits decline and vice versa in times of economic downfall (Akram et al., 2011). But practically there are many limitations of using fiscal policy.

Economic survey of Pakistan 2005-06 segregated objectives of fiscal policy in micro and macro objectives. An equitable distribution of resources, income and social services, increased investment in public goods, fulfilling the basic needs of the poor and enhancing efficiency of public and private enterprises are micro economic objectives and evolution of the economy as a whole is the macroeconomic perspective. Casey McCracken (2006) claimed that it is the responsibility of the government to manage its fiscal policy in an efficient way. The Government should decide about the nature and amount of taxes and expenditures in well-defined manner because taxes and expenditures can affect the incomes and working of the millions of the targeted population. Government can use expansionary or deflationary fiscal stance to meet the above stated objectives.

What will be the shape of the fiscal policy of any country is mostly determined by the political ideology of the political leaders as is claimed by the political economists. According to them distributional conflict on fiscal policy is classified in three categories, first group says that governments try to tie hands of the successors mostly through use of the budget deficit, second group blames policy makers for delaying fiscal decisions and third 
claims overspending is made to create trouble for the upcoming leadership which depend on the personality of the policy maker (Aghion \& Bolton, 1990; Persson \& Svensson, 1989; Alesina \& Tabellini, 1990; Tabellini \& Alesina, 1990; Rogoff \& Sibert, 1988; Rogoff, 1990).

\subsection{Research Question}

Starting from the 1960s, East Asian countries achieved sustained long run GDP growth with the help of persistent and good economic administration. According to Kakar (2011) decline in economic growth is mainly attributed to the same macroeconomic imbalance which has put the nation to the abyss of poverty as well. Kakar (2011) has also suggested that the government should be able to demarcate between the short run and long run objectives of public policy. So the research problem at hand is very much important for the development of a struggling country like Pakistan. Many studies has determined the influence of fiscal policy on the economic development of Pakistan . This paper is also an attempt to identify whether Pakistan has been able to use its fiscal policy to promote its economic growth both in the long or short run?

The paper is arranged as follows: section 1.3 evaluates the theoretical and empirical literature being conducted on the influence of fiscal policy. In section 1.4 we have developed the hypothesis of the study. Section 2 is comprised of data and methodology and section 3 and 4 explains the results and conclude the study respectively.

\subsection{Literature Review}

Wide range of literature is available on the important role of fiscal policy in fastening economic growth. There are two schools of thought who explain the role of public policy in two distinct ways; they are neo classical school of thought and the Keynesians. New classical school of thought blames fiscal policy for creating crowding out of private investment and causing inflation. Increase in the public debt cause an increase in interest rate which put downward pressure on output and inflation. Moreover due to increase in public debt public will anticipate higher taxes in future which further raise labor supply, lower consumption, real wages, current economic activity and inflation (Shaheen and Turner, 2008). All of the economists believe that the classical model holds for the time frame of a decade or more. Afonso et al., (2005) claimed that in addition to economic factors many social, cultural, environmental and geographic factors are involved in the long run so no single explanation can be given to fully predict the behavior of fiscal policy that's why now days the concept of the quality of public finances is becoming popular to improve the role of fiscal policy for raising long run growth potential.

New Keynesian School explains crowding in or multiplier affects in a way that public spending increase demand and economic activity which ultimately leads to make fiscal policy successful (Shaheen and Turner, 2008). In societies with developed and efficient money and capital markets LM curve is perfectly elastic or the IS curve is insensitive to changes in interest rate so in such a situation monetary policy would fail to raise the income and fiscal policy will work here. But economists agree that Keynesians framework only woks in a time span of a few months or less (Afonso et al, 2005).

Literature on fiscal policy can be divided into theoretical and empirical parts; empirical literature on fiscal policy is further divided into following categories: Studies which identify networks through which fiscal policy moves economic growth and empirical studies which explain the progressive or adverse impact of fiscal policy variables on economic progress in long and short time framework.

In empirical studies we first focus on the studies which have identified different channels through which fiscal policy variables exert their impact on economic growth. (Gerson, 1998) identified three types of fiscal policies which can affect economic growth of an economy: Firstly, are the policies which through focusing on education and health level of the workers increase the skill of labor. Fiscal policy through focusing on the development of the human capital and improving the productivity of workers exert positive impact on the economy. Second channel works through increasing the productivity of the stock of physical capital both by increasing the efficacy of the existing capital stock through investing in new projects to build up new physical capital stock. Investment in new technology, infrastructure and research and development via fiscal policy can bring up good outcomes for growth. The fiscal policy which encourages open trade (for facilitating import of modern technology) also proves successful (Barro, 1990). Third are the policies which can increase or decrease the supply of labor and quantity of capital stock through tax incentives or disincentives.

Baldacci et al., (2003) in their paper "Transmission Channels in Low-Income Countries" proved that factor output is the most important channel in developing or low income countries through which public policy enhances economic growth while for developed countries private investment is major transmission route. Their empirical report states that factor product was four times more efficient as a channel to promote economic growth than investment in poor income countries. 
Afonso et al., (2005) have also identified certain channels through which economic progress of a country is moved on by the use of public policy. First identified channel is size of the public sector which can either retard or accelerate economic growth. If the government sector is very large with efficient institutions then it will fasten the pace of economic growth but if large public sector is accompanied with higher tax burdens and inefficient public administration then fiscal policy may fail to increase economic growth. Second is the composition and efficiency of public expenditures which can change the behavior of fiscal policy. If the expenditures are more development oriented i-e development expenditures on infrastructure, education, research and development; and ther are being done in an efficient manner than fiscal policy can be successful. Third is Structure and efficiency of the revenue system like tax system including tax reforms and introduction of less distortionary taxes; is yet another key to success. Fourth one is good fiscal governance as another channel to promote economic growth via fiscal policy. Fifth channel is appropriate functioning of markets and business environment which can be improved via efficient and less distortionary revenue and expenditures systems and through solid fiscal institutions. Jawaid et al, (2011) proved that economic development has a positive relationship with monetary and fiscal policies both in short and long run in Pakistan. In their study monetary policy was found more effective than fiscal policy to enhance growth. Trade policy was also observed as having a very significant affect over the growth rate of Pakistan. Study recommended focusing more on monetary policy to generate increasing pace of economic growth.

Turnovsky (2002) analyzed the working of fiscal policy in an economy with non-scale growth level by taking into account both the public and the private sector and hence found a substantial impact of fiscal variables on growth during transition periods. He suggested that for regulated economy, government investment may bring better results than government consumption.

Dong Fu et al., (2003) analyzed the relationship between fiscal policy and the U.S economy's growth. They used pairwise combination of several fiscal indicators and developed VAR technique to evaluate simultaneous shocks to more than one variables. The technique was used to check the impulse response for coincident, unexpected and corresponding shocks to pairwise mixtures of fiscal indicators. Size of the federal government and economic growth were negatively related for their sample. Deficit came out to be the most inconsistent indicator while tax revenues were the steadiest indicators of fiscal policy.

Gemmell et al., (2006) used panel data of OECD countries and found that in long run; distortionary taxes and productive expenses have an adverse and positive impact on growth of OECD countries respectively. The long run effects were homogeneous in all of the OECD countries while the short run effects were quite different in all such countries. These long run effects were mostly achieved within the time frame of 1-3 years. The Short run effects were significant and persevering provided that the fiscal policy changes were not retreated. This result was also supported by Knellera, (1999) who explored that economic growth is adversely influenced by distortionary type of taxes and positively influenced by productive government expenditures.

McCracken (2006) also analyzed fiscal policy growth via geographical analysis and by using two models one of which disaggregated the fiscal variables. He identified negative relation between government size and growth with transfer payments and income taxes having the most harmful impact. (area of study and the sample size). Ogbole et al., (2007) conducted a comparative study to analyze the difference in growth behavior during regulation and deregulation period of Nigerian economy. They used the time series data taken from central bank of Nigeria. Impact of fiscal policy to enhance growth was different during regulation and deregulation periods. GDP was $14 \%$ higher in deregulation period as compared to regulation period. An appropriate policy mix, prudent public spending, setting the rational fiscal policy targets and broadening the country's economic base was recommended by the authors to enhance growth of the economy.

Romer \& Romer (2007) by using narrative records assessed impact of taxation on economic movements to explore magnitude, timing and principal incentive for all chief postwar tax policy activities. Study found tax increases to be highly contractionary. Results were more significant, robust and much larger than the estimates attained by using wider measures of tax. Higher tax on investment creates larger effects on GDP than other taxes. Conclusion of the study was that reductions in budget deficit through legislated tax increases create less output costs than other type of taxes. Babalola \& Aminu, (2010) employed co-integration technique to assess the association between public policy and Nigerian's economy development. He found an encouraging and long run productive expenditure impact on growth during the studied period. He suggested enhancing government productive expenditures on schooling, health and economic amenities to increase economic progress.

On the other side Kalle Kukk (2007) found no significant influence of fiscal policy on economic progression or development in short run. For example if direct taxes are increased, they will reduce private consumption and increase net exports by the same amount. Thus this tax change does not affect total GDP. While on the other side 
in long run fiscal policy had significant impact on real GDP growth. Tax revenues had positive and expenditures categories had negative impact on GDP but non tax revenues were not significant in general. Only expenditures which had positive impact on GDP growth was spending on public investment. The effect of interest and grant spending was insignificant in many variable combinations. Study recommended government to recognize the fact that change in the composition and categories of revenues and taxes might have same impact on budget balance, total government revenues and expenditures but will have different impact on economic growth.

Shaheen and Turner (2008) also proved the same impact of fiscal policy on macro variables by employing SVAR methodology for the period 1973 to 2008. Their estimates from recursive approach proved insignificant impact of government expenditure shocks on output and inflation. But the results were different as obtained from the Blanchard and Perotti (2002) approach which gave significant impact of government expenditures shocks and taxes on output and inflation in Pakistan. Government expenditures shocks had progressive impact in short run and adverse in the long run and had a tendency to increase over five year period. Interest rate was also increased in sort run due to government shock.

Coming to the time frame of the fiscal policy impact, different studies has identified different time frames for the turnout of the fiscal policy. Gemmell et al., (2011) used panel data of OECD countries since 1970s and found that in long run fiscal structural changes between different forms and types of taxes and spending affect GDP which is realized quite quickly following a few years. Moreover earlier evidence of long run effect seemed to pick up short run and long run effects and long run normally persisted from one to five years of time period. Type of tax and expenditures which is changed determines the impact of changing spending and revenues. For example if the infrastructure spending is financed through highly distortionary taxes, then they will have a negligible influence on GDP growth in long time frame.

\subsection{Hypothesis Development}

Kakar (2011) has discussed that fiscal policy can be used as a tool to boost fiscal sustainability and macroeconomic stability. Pakistan is facing decreasing growth and rising poverty levels due to macro-economic imbalances. Akram et al, (2011) claimed that Pakistan in 1990s had to decrease its budget deficit volume to less than five percent of gross domestic product to meet its rising debt servicing requirements and to fulfill its commitment with IMF under structural adjustment program. All successive governments being failed in revenue generation efforts continued reducing development public spending to resolve budget deficit problem. After 9/11 Pakistan received immense funds under debt relief and debt rescheduling facility which helped Pakistan to increase its development expenditures and consequently experienced a moderate improvement in GDP growth rate, poverty reduction and in social indicators. So we can draw the hypothesis for our study about the fiscal policy effects on GDP growth.

KAKAR, (2011) by employing cointigration technique indicated that fiscal policy significantly affected long run economic development of Pakistan. Moreover he identified that public policy techniques were more important in long run than in short span of time. He suggested controlling interest rate and government expenditures for positive short run outcomes.

On the basis of above quoted study we draw two hypotheses:

$H_{0}$ : Fiscal policy has significant impact on GDP growth of Pakistan.

Our second hypothesis is that

$H_{0}$ : Fiscal policy has both long and short run implications for growth of gross domestic product.

\section{Data and Methodology}

Fiscal policy by enhancing output or productivity affects economic activity and lead to better economic growth and development. The study will use fiscal variables (government consumption expenditures and per capita real total revenues) to identify their impact on GDP growth of Pakistan. We will use discount rate, trade openness and gross fixed capital formation as control variables along with fiscal variables as contributing towards enhancing economic activity. Annual time series data is obtained for the period of 1980-2012 from different sources including WDI and Pakistan Economic Survey. As non-stationarity is a general problem with time series data so Augmented Dickeyfuller test will be used to identify stationarity of the variables. On the basis of ADF test results Johanson cointigration test or ARDL test will be employed to determine long run impact of government fiscal policy on gross domestic product of Pakistan. Moreover error correction model is also used to conclude about short run effects of fiscal policy. Following econometric model is used for empirical analysis.

$$
\left.\operatorname{InGPCC}=\alpha+\beta_{1}(\operatorname{InDR})+\beta_{2}(\operatorname{InTO})\right)+\beta_{3}(\operatorname{InREV})+\beta_{4}(\operatorname{In} G C E)+\beta_{5}(\operatorname{InGFCF})+\mu i
$$


Here:

GPCC $=$ Annual GDP Per Capita (in US\$)

$\mathrm{GCE}=$ Government Consumption Expenditure (Measured in Billion Rupees)

REV $=$ Per Capita Real Total Revenue at constant prices of 1999-2000

$\mathrm{TO}=$ Trade Openness (Measured as ratio of Exports + Imports to GDP)

$\mathrm{GFCF}=$ Gross Fixed Capital Formation (Measured in Billion Rupees)

DR $=$ Discount Rate (\% per Annum)

$\mu \mathrm{i}=$ Error- Correction - Term

\section{Empirical Findings and Discussion}

The ADF test is conducted first of all at level and at first difference. Results of ADF test are showing the stationarity of variables at $1^{\text {st }}$ difference. It means that variables of our model are integrated at the same order (i.e., I (1)).

Table 1. ADF unit root test

\begin{tabular}{|c|c|c|c|c|c|}
\hline \multirow[t]{2}{*}{ Variables } & \multicolumn{2}{|l|}{ Level } & \multicolumn{3}{|c|}{ 1st Difference } \\
\hline & C & $C \& T$ & $\mathrm{C}$ & $C \& T$ & Result \\
\hline LNGPCC & 0.076609 & -1.630809 & $-4.905303^{*}$ & $-5.047286^{*}$ & $\mathrm{I}(1)$ \\
\hline LNGCE & -1.852712 & -2.317313 & $-5.467984 *$ & $-5.770146^{*}$ & $\mathrm{I}(1)$ \\
\hline LNREV & -0.185127 & -2.736503 & $-6.010841^{*}$ & $-5.982361^{*}$ & $\mathrm{I}(1)$ \\
\hline LNTO & 0.100775 & -1.206994 & $-5.008329^{*}$ & $-5.49253^{*}$ & $\mathrm{I}(1)$ \\
\hline LNGFCF & 0.308614 & -2.144261 & $-4.527158^{*}$ & $-4.478101 *$ & $\mathrm{I}(1)$ \\
\hline LNDSR & -2.381442 & -2.322422 & $-3.776731^{*}$ & $-3.690457 *$ & $\mathrm{I}(1)$ \\
\hline
\end{tabular}

Notes: the series is stationary at $5 \%$ level of significance at critical value "-2.976263" for constant and critical value "-3.580623" for constant and trend component.

Table 2. VAR lag order selection criteria

Endogenous variables: LNGPCC LNGFCF LNPEX LNREV LNTO LNDSR

\begin{tabular}{lllllll}
\hline Lag & Log L & LR & FPE & AIC & SC & HQ \\
\hline $\mathbf{0}$ & 18.83368 & NA & $1.66 \mathrm{e}-08$ & -0.88508 & -0.60219 & -0.79648 \\
$\mathbf{1}$ & 168.5870 & $227.2119^{*}$ & $6.90 \mathrm{e}-12^{*}$ & $-8.730136^{*}$ & $-6.749914^{*}$ & $-8.109955^{*}$ \\
$\mathbf{2}$ & 203.3519 & 38.36133 & $1.07 \mathrm{e}-11$ & -8.64496 & -4.96741 & -7.4932 \\
\hline
\end{tabular}

Note: * indicates lag order selected by the criterion. LR: sequential modified LR test statistic (each test at 5\% level); FPE: Final prediction error; AIC: Akaike-information criterion; SC: Schwarz-information criterion; HQ: HannanQuinn information criterion.

One lag has been selected by all the criterias. Maximum one lag has been selected by sequential modified LR test statistic (each test at 5\% level), Schwarz information criterion, Akaike information criterion, Final prediction error and Hannan-Quinn information criterion. Instead of Engle-Granger single equation based cointegration test, Johanson $(1988,1991)$ and extended by Johanson and Juselious (1990) is applied. Johanson and Juselious (1990) have derived two tests (Trace test and Maximum Eigen Value test) for cointegration. The result of Trace and Maximum Eigen Value test statistic are shown in table 3 and 4.

Table 3. Unrestricted co-integration rank test (trace)

\begin{tabular}{lcccc}
\hline Hypothesized at & & Trace & $\mathbf{0 . 0 5}$ & Prob.** \\
\hline No. of CE(s) & Eigenvalue & Statistic & Critical Value & 0.0000 \\
\hline None * & 0.754744 & 116.4283 & 83.9371 & 0.0014 \\
At most : $\mathbf{*}$ & 0.705895 & 75.67022 & 60.0614 & 0.0500 \\
At most :2 & 0.486655 & 40.17946 & 40.1749 & 0.1276 \\
At most :3 & 0.380402 & 20.84205 & 24.2759 & 0.3291 \\
At most :4 & 0.173676 & 6.960194 & 12.3209 & 0.2718 \\
At most :5 & 0.048046 & 1.427916 & 4.1299 & 0.05 leve \\
\hline
\end{tabular}

Notes: Trace test indicates 3 cointegrating eqn(s) at the 0.05 level. * denotes rejection of the hypothesis at the 0.05 level; **Mackinnon HaugMichelis (1999) p-values. 
Table 4. Unrestricted co-integration rank test (maximum eigenvalue)

\begin{tabular}{lcccc}
\hline Hypothesized at & & Max-Eigen-value & $\mathbf{0 . 0 5}$ & \\
\hline No. of CE(s) & Eigenvalue & Statistic & Critical Value & Prob.** \\
\hline None * & 0.754744 & 40.75809 & 36.6301 & 0.0156 \\
At most: $\mathbf{~ *}$ & 0.705895 & 35.49075 & 30.4396 & 0.0108 \\
At most : & 0.486655 & 19.33742 & 24.1592 & 0.1970 \\
At most :3 & 0.380402 & 13.88186 & 17.7973 & 0.1764 \\
At most: 4 & 0.173676 & 5.532278 & 11.2248 & 0.4060 \\
At most :5 & 0.048046 & 1.427916 & 4.1299 & 0.2718 \\
\hline
\end{tabular}

Notes: Max eigenvalue text indicates 2 cointegrating eqn(s) at the 0.05 level. * denotes rejection of the hypothesis at the 0.05 level; **MacKinnon HaugMichelis (1999) p-values.

The above table shows that Trace and Maximum Eigen Value statistics are above the critical value of 5 percent. Hence we reject the null hypothesis of no co-integration. Therefore, the results confirm the long run relationship of economic growth with fiscal policy variables.

Table 5. Normalized co-integrating coefficients

\begin{tabular}{llllll}
\hline LNGPCC & LNGFCF & LNGCE & LNREV & LNTO & LNDSR \\
\hline $\mathbf{1}$ & 1.278568 & -1.245848 & 0.507 & 1.05375 & 0.1247 \\
S.E & 0.11434 & 0.12608 & 0.03111 & 0.15280 & 0.06058 \\
t Ratios & 11.18217597 & -9.881409 & 16.29701 & 6.89627 & 2.058435 \\
\hline
\end{tabular}

From the results of the normalized cointegrating coefficients we can clearly conclude that fiscal policy has significant impact on the GDP growth of Pakistan. Gross fixed capital formation, trade openness and discount rate have positive and significant impact on the long run growth path of Pakistan. The analysis indicates a significant impact of public expenditures and revenues on the GDP as well. Government consumption expenditures have negative impact on the GDP per capita while the real total revenues have positive signed coefficient which means if the government is able to acquire greater revenues then it will be able to spend more on all the expenditures categories including spending on infrastructure, education, health and public welfare works which will lead to improve the GDP growth of the country.

Table 6. Error-correction model

\begin{tabular}{lllllll}
\hline Error-Correction: & D(LNGPCC) & D(LNDSR) & D(LNGCE) & D(LNREV) & D(LNTO) & D(LNGFCF) \\
\hline CointEq-1 & -0.3751 & -0.4653 & -0.30269 & -0.37526 & 0.575456 & 0.013882 \\
& $(0.15666)$ & $(0.32301)$ & $(0.27147)$ & $(0.09338)$ & $(1.82279)$ & $(0.21429)$ \\
& {$[-2.39437]$} & {$[-1.44050]$} & {$[-1.11501]$} & {$[-4.01858]$} & {$[0.31570]$} & {$[0.06478]$} \\
\hline
\end{tabular}

The error correction coefficient is -0.3751 with t-statistic value of -2.39437 . It shows the error correction term is significant. The error correction sign should be negative. It indicates that approximately $37 \%$ of the disequilibrium error is corrected in each period and it suggests a good speed of convergence towards equilibrium if there appears any disequilibrium. The negative sign of error correction term is in accordance with the theory. Public expenditures, discount rate and public revenues have also tendency to converge to their long run equilibrium.

\section{Conclusion and Policy Implications}

Impact of fiscal policy variables on short and long-run growth of Pakistan was the main objective of the study. So it has been tested on the basis of theoretical literature and empirical testing of data on Pakistan's economy for the period 1980-2012. For theoretical determination we have reviewed several empirical studies. From all of the literature reviewed we conclude that fiscal policy is very important for macroeconomic stability of the economy and for attaining sustained economic growth. For empirical determination of the importance of fiscal policy for Pakistan we have employed Johansen co-integration test for anticipating long-run performance of the fiscal variables, and vector error-correction model is operated to identify the existence of error correction term in our model. Empirical findings show that public policy is very vital for meaningful economic progress and results also point to the fact that public policy techniques are more meaningful for long run growth then in short time frame in Pakistan. Moreover from earlier studies we conclude that the structure, efficiency and composition of 
the expenditure and revenue system are most important to make fiscal policy effective. The study has established a negative relation of government consumption expenditures with GDP and public revenues has a progressive impact on economic activity of Pakistan. Less consumption expenditures and effective revenue structure can help Pakistan to boost its lethargic growth rate. Institutional structure which governs fiscal policy making and the system in which fiscal policy is implemented also play an important role in this regard. Policy must be credible means people must have confidence in government decisions. There should be more productive expenditures and less distortionary taxes. With proper implementation and continuity of the fiscal decisions, fiscal policy can better lead to sustained economic growth along with other macro policy measure.

\section{References}

Afonso, A., \& Sousa, R. M. (2009). The Macroeconomic Effects of Fiscal Policy. Working Paper Series, 991.

Afonso, A., Ebert, W., Schuknecht, L., \& Thöne, A. M. (2005). Quality of Public Finances and Growth. Working Paper Series, 438.

Akram, N., et al. (2011). Fiscal Situation in Pakistan and its consequences for Economic Growth and Poverty. American International Journal of Contemporary Research, 1(1).

Babalola, S. J., \& Aminu, U. (2013). Fiscal Policy and Economic Growth Relationship in Nigeria. International Journal of Business and Social Science, 2(17).

Berkmen, S. P. (2011). The Impact of Fiscal Consolidation and Structural Reforms on Growth in Japan. IMF Working Paper Asia and Pacific Department, WP/11/13.

Committee, D., et al. (2007). Fiscal Policy For Growth And Development: Further Analysis And Lessons From Country Case Studies. Internat Ional Bank For Reconstructio N And Development.

Easterly, W., \& Rebelo, S. (1993). Fiscal Policy And Economic Growth: An Emperical Investigation. National Bureau Of Economic Research, Working Paper, No. 4499.

Fueki, T., Fukunaga, I., \& Saito, M. (2011). Assessing The Effects Of Fiscal Policy In Japan With Estimated And Calibrated DSGE Models. Bank Of Japan Working Paper Series, No.11-E-9.

Gemmell, N., Kneller, R., \& Sanz, I. (2006). Fiscal Policy Impacts on Growth in the OECD: Are They Long- or Short-Run?

Gemmell, N., Kneller, R., \& Sanz, I. (2011). Fiscal Policy: New Cross-Country Evidence Of The Impact On Short- And Long-Run Growth. The Economic Journal.

Gerson, P. B. P. (1998). The Impact of Fiscal Policy Variables on Output Growth. IMF Working Paper, 1(98).

Gupta, S., Clements, B., Baldacci, E., \& Granados, C. (2005). Fiscal policy, expenditure composition,and growth in low-income countries. Journal of International Money and Finance, 24, 441-463. http://dx.doi.org/10.1016/j.jimonfin.2005.01.004

Jawaid, S. T., Qadri, F. S., \& Ali, N. (2011). Monetary-Fiscal-Trade Policy And Economic Growth In Pakistan: Time Series Empirical Investigation. International Journal Of Economics And Financial Issues, 1(3), 133-138.

Kakar, Z. K. (2011). Impact Of Fiscal Variables On Economic Development of Pakistan. Romanian Journal of Fiscal Policy, 2(2), 1-10.

Knellera, R., Bleaneyb, M. F., \& Gemmellb, N. (1999). Fiscal policy and growth: evidence from OECD countries. Journal of Public Economics, 74, 171-190. http://dx.doi.org/10.1016/S0047-2727(99)00022-5

Long, J. B. D., \& Summers, L. H. (1992). Macroeconomic Policy and Long-Run Growth.

López, R. E., Thomas, V., \& Wang, Y. (2010). The Effect of Fiscal Policies on the Quality of Growth. The World Bank. Washington, D.C.

Mccracken, C. (2006). Whether State Fiscal Policy Affects State Economic Growth.

Nurudeen, A., \& Usman, A. (2010). Government Expenditure And Economic Growth In Nigeria, 1970-2008: A Disaggregated Analysis. Business and Economics Journal, BEJ-4.

Ogbole, O. F., Amadi, S. N., \& Essi, I. D. (2011). Fiscal policy: Its impact on economic growth in Nigeria 1970 to 2006. Journal of Economics and International Finance, 3(6), 407-417.

Romer, C. D., \& Romer, D. H. (2007). The Macroeconomic Effects Of Tax Changes: Estimates Based On A New Measure Of Fiscal Shocks. 
Shaheen, R., \& Turner, D. P. (2010). Measuring the dynamic Effects of Fiscal Policy shocks in Pakistan.

Thomas, V., et al. (2010). The Effect of Fiscal Policies on the Quality of Growth. The World Bank. Washington, D.C.

Zee, V., \& Tanzi, V. (1997). Fiscal Policy and Long-Run Growth. Palgrave Macmillan Journals, 44(2), 179-209.

Notes

Note 1. http://info.worldbank.org/governance/wgi/index.asp

Note 2. http://www.wvsevsdb.com/wvs/WVSData.jsp 